Driven to excess? Linking calling, character and the (mis)behaviour of marketers (c) The Author(s) 201I

Reprints and permission: sagepub.co.uk/journalsPermissions.nav DOI: $10.1|77 /| 470593$ |||4|8797 mtq.sagepub.com

@SAGE

\title{
Tony Woodall
}

Nottingham Trent University, UK

\begin{abstract}
We are presently at a point of unique circumstantial convergence where recession, an increased emphasis on business ethics, and marketer's reluctance to accept shifting social agendas have combined to identify the need for a new approach to marketing. Using concepts from the human resources, marketing and psychology literatures, and especially Erich Fromm's ideas concerning economic character, this paper posits that marketers - as a professional community - are driven to promote consumerist outcomes; victims of an automaton amalgam of calling and character. The analysis suggests the vulnerability of both marketer and consumer are mutually reinforcing and that we need, somehow, to break this damaging cycle of dependence. We know little, however, about how marketers think and feel about their discipline, so this paper also promotes an agenda for marketer behaviour research, as a countervailing balance to a currently disproportionate focus on the consumer.
\end{abstract}

\section{Keywords}

Erich Fromm, job fit, marketer behaviour, marketing ethics, personality, recession

Paradox is the essence of contemporary business. While, on the one hand, the literature pays homage to, and expresses the need for, trust (Arnott, 2007), corporate social responsibility (Carroll, 1999), marketing ethics (Martin and Johnson, 2008) and a greener world in which to express and cherish those laudable aspirations (McDaniel and Rylander, 1993), the global banking industry has proved once again what society has always known; that marketing and marketers are intractably 'hard-wired to the hard-sell' (Woodall, 2007). Reichheld (1996) warned more than a decade ago that commercially - let's not even think ethically - 'adverse selection' (making the offer too good/

\section{Corresponding author:}

Tony Woodall, Nottingham Trent University, Division of Marketing, Retail and Operations, Nottingham Business School, Burton Street, Nottingham, NGI6 2TG, UK

Email: tony.woodall@ntu.ac.uk 
easy; recruiting from 'wrong', often most vulnerable, customers) would lead to tears; and so it has proved to be. The sub-prime mortgage (Samuelson, 2007), the NINJA loan (Pearlstein, 2007) and other similar manifestations of a recent and largely untrammelled growth of consumer debt (Mackrill, 2007) have all been indelibly marked with the lineament of Vance Packard's (1957) 'hidden persuaders'. Via an artful array of 'excesses, scams, malfeasance, and misdemeanours' (Schultz, II and Holbrook, 2009: 125), marketers have found myriad ways of alchemizing latent consumer frailty and, in the process, have created a globally debilitating mountain of fool's gold. That extra customer; that additional sale; the sheer thrill of that one-point growth in market share, has always meant more than a responsibly earned and sustainable relationship.

This paper takes the above as a point of departure and speculates on key factors underlying continuing manifestations of marketer (mis)behaviour. It ends with an agenda for research focusing on the need for more, and deeper, study into practitioner manners and deeds. The intervening argument comprises a brief review of what we know/don't know about the attitudes of practising marketing managers; a discussion on the relationship between people and the jobs they hold; and, finally, a consideration of the character of marketers viewed via a post-Freudian perspective on individual difference. The key objective of the paper is to encourage a more critical and analytical review of those who represent, in the commercial world, the art and science of marketing - and, via this process, to help engender a closer alignment between marketing endeavour and the needs of society.

\section{The news is not good ...}

This paper opened with a brief and damning commentary on the liability of marketers in the context of the recent, global, economic downturn. It suggested a largely sales-driven approach to the market; a focus on revenue maximized at all costs; and implied a discipline committed to specious and illusory modes of practice - and this is far from a personally determined construction of the issue. Sheth and Sisodia (2005) for example reported on US research, suggesting that $62 \%$ of consumers think negatively about marketers, and that only $10 \%$ would articulate positively on their merits. Heath and Heath (2008) uncovered evidence of similar mistrust in Portugal. O'Malley and Prothero (2004) earlier identified general suspicion regarding even the most laudable of marketing practices (customer care and loyalty programmes), while later commercial research by Harris International (i-level, 2009) suggests that two out of three people in the United States blame advertising for the recent recession. So far, so bad.

Interestingly, in a recent longitudinal investigation of New Zealanders' attitudes toward the free market philosophy (Lysonski et al., 2003; comparing the years 1986 and 2001), there appeared evidence of a society increasingly more at ease with the general marketing landscape; but while suppliers were perceived to be more aware of their responsibilities in terms of quality, the environment and product legislation, there was continued mistrust of pricing and advertising - areas most likely to be influenced by the marketing manager. Society at large, therefore - in whichever part of the world one might choose - clearly thinks little of the marketer's propensity to act for the collective good, and the notion of marketer-as-misanthrope continues to pervade the popular view. Even in the organization marketers are viewed with suspicion, Baker and Holt (2004: 557) recently revealing evidence of senior management distrust of 'unaccountable, untouchable, slippery and expensive' marketing colleagues; hardly a ringing endorsement for a discipline that, according to Mattson et al. (2006), should be at the heart of corporate strategy. So for marketing, and marketers, the news is not good. Perceived at least partially responsible for a global collapse of confidence 
in financial markets, and held as malicious, untrustworthy and inept from both sides of the organization/market dyad, they appear less than safe.

For some, though, this parade of knavish disreputability is precisely what makes marketing work, and it continues to inform and reinforce a darkly romanticized view of what our discipline is, and should be. For example much of Stephen Brown's more recent and managerially focused work, concentrating on a largely 'one-'P', (promotion, promotion, promotion) approach to marketing (Woodall, 2001), supports this perspective. Eulogizing marketing's 'tricksterist credententials', Brown has lauded the exploits of diverse marketing heroes - from P.T. Barnum the circus entrepreneur (Brown, 2001) and, via Elbert Hubbert of the Roycrofters' furniture workshops (Brown, 2006); Roger Ackerley of Fyffes banana fame (Brown, 2000); and even Jesus Christ (Brown and Patterson, 2000) - to IBM's T.J. Watson (Brown, 2007a) and Ryanair's 'headlinegrabbing, publicity-stunt pulling' Michael O'Leary (Brown, 2007b: 3), and has attempted to endear to us the notion of a discipline 'characterized by exaggeration, by excess, by extremity, by exuberance, by extra, extra, extra' (Brown 2001: 199-200). But while arguments for an 'authentic' and transparently manipulative approach to marketing - especially in the context of a reflexively artful marketplace - have been forcibly made (e.g. Firat and Venkatesh, 1995), there is now a growing sense that consumers in general are not as smart as marketing's apologists (including this author) have suggested, and that (some of) the postmodern runes may have been incorrectly cast.

\section{A shifting marketing landscape}

Critics of the marketing project have for many years, of course, been aware both of marketing's image problem (a delightful irony) and of society's potentially countermanding imperatives (see Farmer, 1967, 1977 - would you let your son/daughter marry a marketing woman/man?). Both are conjoined in the context of marketing ethics, and more recently much has been written defining and/or contesting what this might actually be (e.g. Brinkman, 2002; Gaski, 1999; Martin and Johnson, 2008; Mayo and Marks, 1990; Vitell and Hunt, 1990); while concern for the ethical validity of specific marketing practices continues to attract researcher attention (e.g. Kelly and Smith, 2008 - stealth marketing; Borgerson and Schroeder, 2002 - marketing representation; Vikas and Varman, 2007 - selling to vulnerable groups). Except on rare occasions (e.g. Singhapakdi et al., 2008) study concerning the ethical mores of the marketing manager him/herself, though, has concerned itself primarily with ethical behaviour at work, rather than in the marketplace - see, for example, Ferrell and Weaver, 1978; Fritzsche and Becker, 1983; Singhapakdi et al., 1996, 2010 - and has tended to focus on factors influencing ethical behaviour and the extent to which the organization guides or determines managers' actions (e.g. work climate - Deconinck, 2004; institutionalization of ethics - Singhapakdi and Vitell, 2007; ethical sensitization - Marta et al., 2008b). Often, too, concern with the marketer is framed as being incidental to some more central interest, such as cultural/national difference (Karande et al., 2002; Marta et al., 2008a), gender (Daulatram, 2008), or religion (Gibbs and Ilkan, 2008), with outcomes focused more on managerial, rather than market, decision making.

The literature associating marketing and ethics is substantial (for a review see Schlegelmilch and Öberseder, 2010) but the link between the practising marketer and marketing practice is rarely explored. Yet we are presently at a point of unique circumstantial convergence, where an interest in business ethics; damning evidence of continuing marketer indulgence; and calls for marketing to adopt a more defensive (Woodall, 2004; Woodall and Swailes, 2009), advocatory (Lawer and Knox, 2006; Urban, 2005), promise keeping (Grönroos, 2006), virtue-based (Murphy et al., 2007), 
matriarchal (Scott and Peñaloza, 2006), even humble (Cova, 2005), approach, have combined to identify the need for a different type of marketer - one that is holistically and intuitively suited to the demands of a different type of marketing, where individual values, attitudes and ethics are likely to be as important, if not more, than the ability to plan and execute a promotional campaign. The age of service (Vargo and Lusch, 2008), customer experience (Berry et al., 2002) and word of mouth (Kumar et al., 2007) is clearly upon us, yet there is a sense that marketers are struggling to understand how performance, rather than persuasion and a larger-than-life espousal of the possible, will win out in the longer term.

\section{Right for the job?}

For the past decade or so the literature has obsessed on the notion of the 'right' customer (e.g. Kumar, 2008; Reichheld, 1996; Rust et al., 2004; Saarksjarvi et al., 2007). Little, however, has been written on reciprocal issues; that is, on where/how we might find the 'right' marketer. Ultimately, of course, marketing is a function of the behaviour of marketers, especially of marketing managers. As a professional community marketing managers are self-contained - the academies, professional bodies, and academic literature exert their pull, as do equally trade journals, airport schlock and peer-to-peer networks - all contributing to establish a collective (though infinitely textured) modus operandi that, ultimately, defines how sales and marketing happens in the 'real' world: the 'grand competence' (Peters et al., 2009) that represents what marketing is and does. The manner in which marketing managers behave, therefore, and the way they interpret the demands placed upon them by both employer and society, are - to a substantial degree - selfdetermined. From a corporate perspective they may be encouraged toward a specific end, but both strategically and tactically are given scope and latitude to practise in accordance with internally normalized imperatives.

The marketing rhetoric, channelled via the 'gurus' of the marketing domain, holds that marketers are guided by one overarching credo: the maximization of customer satisfaction (Day, 1994; Jobber, 2010; Kotler, 1972). But to what extent are marketers really committed to the customer cause? Stock and Hoyer (2005) argue that business employees may well often 'act' in a preferred manner - that is, demonstrate behavioural, managerial, even theoretical, compliance (Brill, 1994) - but may not possess a natural allegiance, or real enthusiasm, for a particular credo or policy. Bardzil and Slaski (2003) call such allegiance 'critical internalization', and suggest that certain attitudes (service orientation, in their case) may be innate. Thus, although uncommitted employees may be able to process certain attitude-level modifiers; profess devotion to a cause; and perform in an apparently appropriate manner, this may only be a temporary or spurious effect. Järlström (2000: 146) cites McDaid et al., who suggest that 'people differ in the ways they like to use their minds, and ... these differences influence the ways people like to work, what motivates them and what satisfies them'. Some 20 years ago Carter (1985: 53) asked,

Are we guilty, perhaps, of not addressing the fundamental question as to whether the marketing personnel we employ ... are really right for the job - and not in the sense that they are either efficient or effective or even physically or personally suited, but that the task demanded of them is not in keeping with their preferred way of doing things - a personality which, although capable of being situation-specific, eventually re-asserts itself? 
Marketing jobs are rarely advertised without resort to a lexicon of aspirational and/or superlative epithets - fun, exciting, quick-thinking, fast-paced, fast-moving, aggressive, passionate, entrepreneurial, innovative, creative, cutting-edge (e.g. Monster, 2009; Simply Marketing Jobs, 2009). This aligns strongly with the findings of Rallapalli et al. (2000), who identified 'excitement' and 'fun and enjoyment in life' as the two primary personal values of marketing practitioners. Marketing, as a career, is perceived to be, and projected as, exhilarating and glamorous - also, perhaps, edgy, dangerous, and alluringly disreputable. Johnson et al. (2008) demonstrated an 'attractiveness' relationship between personality and job advertisement text and, according to Ehrhart (2006), job-seekers readily form personality related 'job characteristic beliefs' from relevant sources of information.

Does marketing, then, both by heritage and design, attract the risk-taker, the hedonist, the ethically ambivalent - and do job advertisements merely reinforce the expectations of those who want to be marketers, rather than target those who might be best at doing it? Are employers, in one respect, recruiting the 'wrong' people? And if, indeed, our marketing recruits are inherently 'hard-wired to the hard-sell', to what extent will they be able to resist the siren call of consumerist dissipation once the newspapers have moved from the recession to different, more instrumentally urgent, agendas?

\section{Marketing and personality}

To further examine this premise we need to understand what it is that determines how/why a particular individual comes to occupy a specific job. The literature suggests there is a tension between the individual finding the job that is best for them, and the employer finding the person best suited to the job to be done. The key task for both is, essentially, to achieve optimum 'personenvironment' (Carless, 2005), or 'person-situation' (Tett and Burnett, 2003) fit, and it is argued that it is ultimately the employees' search for job satisfaction that drives the fitting process (Converse et al., 2004). Thus, a gravitational outcome is hypothesized; one that causes individuals to 'sort themselves' into jobs for which they are especially suited or find notably attractive (Wilk et al., 1995). As Celmer and Winer (1990: 178) suggest, people 'search for environments that will let them exercise their skills and abilities, express their attitudes and values'. Schein (1996) argues that we are all in search of one or more 'career anchors', and that we will continue to search until we find them, while Arvey et al. (cited in Furnham, 2001: 229) suggest there is a certain inevitability that guides the pace and nature of our career trajectory. Ultimately, a person can only be fully satisfied in his/her work if the occupational environment is congruent with the individual's interests, values and abilities (Thomas et al., 2004) or, and perhaps most importantly, their personality (Brown et al., 1989).

In the same way, though, that there is little written about marketing (as opposed to managerial) ethics, the literature that relates to individual difference (attitude, orientation, personality) in the context of marketing managers is sparse (Woodall and Swailes, 2009). Although there is a substantial body of work (e.g. Chang, 2006; Farrell and Oczkowski, 2009; Franke and Park, 2005; Harris and Fleming, 2005; Sawyerr et al., 2009; Verbeke and Bagozzi, 2002) relating to customer facing, or 'part-time' (Gummesson, 1991) marketers - service workers, sales personnel, call centre agents - those who market strategically, or 'full-time' appear largely immune to researcher interest. Some commentators (e.g. Ardley, 2005; Brady and Palmer, 2004; Clark, 2000; Coviello et al., 2002; Morgan et al., 1995) have explored marketing manager habits or working preferences, but research associating 'marketer' and 'personality' is rare - and even in the journal Psychology 
and Marketing, articles focused on the full-time marketer, and the way that he/she thinks or believes, are uncommon - Forlani et al. (2002) and Weber (2001) being rare exceptions.

The academic canon contains some, but only a few, papers that seriously address marketers from a psychological perspective (e.g. Carter, 1985; Elliot and Margerison, 1977; Hunt and Chonko, 1984; Nordvik, 1996), and in the marketing literature generally, the terms 'marketer' and 'personality' are far more likely to be aligned with the notion of 'owning' or 'demonstrating' personality, in much the same way that brands are suggested to have personality (e.g. Aaker, 1997; Arora and Stoner, 2009; Geuens, 2009; Hayes et al., 2006). For example the abstract for a magazine article called 'Brand Names: The Folks behind the Best Work of 2002' (Promagazine, 2003) reveals that this item 'profiles marketing personalities nominated as the "Promo" magazine's Marketers of the Year for 2002'. Another informs us of a similar piece titled, 'Makin' Your Marketing Personality Work for You' (McPherson, 1996), and yet another (Kucharsky, 2002) again on annual awards - advises 'Jaques Nantel's got personality'. Newlin (2002) discusses 'marketing with personality' (give your marketing some 'oomph'!), and Young (2004) comments on articles written by 'leading Canadian marketing personalities', while Search Engine College (2009) even lists the top 22 'personalities' presently working in the marketing field. Of course, this specific association between 'marketing' and 'personality' reinforces stereotypical perspectives that presume the overriding importance of personal projection and the primary value of a largerthan-life approach to customer engagement. Roberts and Hogan (2001: 11) refer to this interpretation of personality as 'the distinct impression a person makes on others' and, intuitively, we associate the ability to 'make an impression' as a sign of a good marketer.

\section{The marketing character}

Stephen Brown's heroes - introduced above - however, are marketers only via the broadest of interpretations. People like Barnum, Watson and O'Leary are essentially super-entrepreneurs, individuals for whom personal promotion is integral to a more diverse and complex set of intrinsic attributes almost, perhaps, better framed as a psychosis than a personality. Maccoby (2004) touches on similar ground in a paper that suggests many of today's more interesting and successful business leaders (e.g. Microsoft's Bill Gates and GE's Jack Walsh) display all the characteristics of Freud's 'narcissistic' type; those who have a neurotic need for social recognition, prestige or power. But interestingly he focuses, too, upon what he claims to be the much more frequently encountered, perhaps even the most common, type of leader/manager - the one who exhibits a 'marketing personality'. Such leaders are less driven but, as Maccoby claims elsewhere, 'have a radar sensitivity to people and their needs' (Master, 2003: 14), are good at networking, and thrive on change - though 'sensitivity' here is used as meaning sensibility rather than empathy.

Maccoby's ideas concerning 'marketing personality' are neither recent, nor novel. Maccoby worked closely with Erich Fromm (Fromm and Maccoby, 1970), and thoughts expressed are derived directly from Fromm's 'marketing character' which, in the original (Fromm, 1949), is a phenomenon relating more to society than to any aspect of the firm. Saunders and Munro (2000: 219) identify Fromm's 'marketing character' as being underpinned by 'the notion that the self may be experienced as a commodity whose values and meaning are externally determined'; it is used to explain why, in order to escape from post-industrial freedom and the associated responsibility it brought (Fromm, 1941), many search for mechanisms that allow them to hide their 'real' selves from society and, instead, operate on a more superficial, consumerist, level. In some respects this reflects Durkheim's notion of anomie (see Olsen, 1965), a dysfunctional response to the dissipation 
of regulating norms, especially following incidences of major societal change. Individuals may become, essentially, 'social tourists' (Fromm, 1979) whose second-hand experiences stand proxy for 'real' life, vicariously lived at one remove through the products they own and/or consume. Materialism, suggest Chang and Arkin (2002), is one potential response to anomie.

As Freudian revisionist and cultural anthropologist Erich Fromm established a substantial reputation for psychological innovation immediately before and after the Second World War (McLaughlin, 1998). He redefined 'sanity' as a moral condition (Fromm, 1955 [1991]) and drew parallels between the individual and the society/political system in which they lived. Owing partly to a broadly popularizing stance, though (his best known book is The Art of Loving [Fromm, 1956]), he was ultimately scorned by the intellectual elite (Elkind, 1981); and by the 1970s had, effectively, become a marginalized figure, mocked for a simplistic approach to the correction of society's ills (Black, 1984). Fromm's contributions to the study of psychology, however, are numerous (see Boeree, 2006) and more recent re-evaluations of his work (e.g. Gruba-McCallister, 2007; McLaughlin, 1998; Maycroft, 2004; Rasmussen and Sulhani, 2008) have led to something of a rehabilitation, primarily because of the anti-capitalist nature of his ideas (Green, 1946; Rickert, 1986). In recognition of his pioneering/prophetic warnings regarding the growth and danger of what de Graaf et al. (2001: 2) call affluenza, 'a painful, contagious, socially transmitted condition of overload, debt, anxiety, and waste resulting from the dogged pursuit of more', Davis (2003) suggests Fromm was an 'affirmative postmodernist', someone who was able to provide insights into a broadly postmodern, post-war, condition, but who was not indifferent to traditional perspectives on what might be considered ethical and/or good.

\section{Economic character and orientation}

As indicated earlier, one of Fromm's more interesting ideas pertains to a wider account of personality in the context of economics and society. Thus, Fromm (1949) not only defined the 'marketing character' as being one of the key traits of contemporary American society, he also identified 'marketing orientation' (not the same as market orientation; Kohli and Jaworski, 1990, or Narver and Slater, 1990) as one of five socio/economically based personality categories; others being the receptive orientation, the exploitative orientation, the hoarding orientation and the productive orientation. And while the marketing personality/orientation is associated with man/ woman as consumer it does not, as demonstrated by Maccoby (2004), take a major stretch of the imagination to see how that contemporary consumer might take his or her 'character' into the workplace and use it as a means of personal promotion; and how, by a student of leadership, this might be seen as exemplifying a particular type of manager; one who wishes to make an impression - perhaps, even, to be a 'marketing personality'. Willy Loman, the key character in Arthur Miller's Death of a Salesman, is identified as such a type (Pendse, 1978), focusing on 'show' and edifice, used primarily as a means to sell himself.

Equally interesting - in the context of this present paper - are Fromm's insights into the 'receptive' and 'exploitative' orientations. The former is characterized as follows: 'This subtle but rather general receptiveness assumes somewhat grotesque forms in modern "folklore", fostered particularly by advertising. While everyone knows that "get-rich-quick" schemes do not work, here is a widespread daydream of effortless life' (Fromm, 1949: 80). Here, perhaps, is the ideal dupe; the easy, but potentially 'wrong' customer who, according to Reichheld (1996), is easily seduced - but offers little by way of profitable loyalty. By contrast, the exploitatively oriented character, whose credo is 'I take what I need', is likened to Marx's free market 'pariah' or 
'adventure' capitalist, whose main aim is to 'buy cheap and sell dear'. Individuals (customers?) are merely 'to be used and exploited ...' (Fromm, 1949: 108), promised, via a process of 'benevolent sadism', all that they needlessly desire. The 'hoarding' character is different from both the 'receptive' and 'exploitative' characters but no less unattractive - at least to the marketer. For while marketing, receptive and exploitative characters have a tendency always to say 'yes', the hoarder is prone to say 'no'.

Meisenhelder (2006) notes that Fromm believed economic structures to be as important in determining behaviour as any other socializing factor (e.g. family, education) and that specific character types become 'embodied' in specific economic contexts. Fromm's work with Macoby (Fromm and Maccoby, 1970, focusing on a village community in Mexico) sought and, Fromm believed, validated, his hypothesis. Fromm wrote that social character 'internalizes external necessities and thus harnesses human energy for the tasks of a given economic and social system.' (Meisenhelder, 2006: 311). Thus it might be suggested that people subconsciously adopt particular roles in society (and business) as means of realizing, or externalizing, their true personality, especially in free market cultures (Walsh-Bowers, 1993).

It might be suggested, too, that the 'marketing' character, or personality, is represented on both sides of the marketer/customer dyad, relying on, and feeding off, a reciprocal need for conspicuous display. As customer, the marketing character demands the goods and services necessary to sustain an overtly enviable lifestyle; while as marketer, this same character type is compelled to impress by maximizing short-term sales - through whatever means might be necessary; and life in the perpetual present (Baudrillard, 1988) is the objective for both. 'Receptive' and 'exploitative' types are, perhaps, similarly conjoined - inevitably and mutually attracted, colliding in the marketplace in a spiral of inflationary waste. Here we might see both 'wrong' customer and 'wrong' marketer respectively, reflecting and reinforcing shared nihilistic tendencies, collectively licensing a kind of intellectual torpor, causing each to accede to the other. Schultz, II and Holbrook (2009: 124) are clear that 'vulnerability creates its own insidiously self-reinforcing cycle' and, through a Frommian lens, it is possible to see both customer and marketer displaying interdependent frailty - two 'living machines' (Green, 1946), or 'interchangeable commodities' (Rasmussen and Sulhani, 2008) programmed to capitalize on each other's weaknesses: the one intemperately amenable, and the other too willing to take unfair advantage. And although it would not be appropriate to tag marketers per se as being singularly responsible for all the excesses of a consumerist society - nor to suggest that all marketers conform to Packard's (1957) exploitative template - there is enough circumstantial evidence to suggest that, as a broad professional community, they appear driven to this end; victims, perhaps, of an automaton amalgam of calling and character.

\section{The productive orientation}

Schultz, II and Holbrook (2009: 125) are withering in their condemnation of the worst excesses of marketing practice - 'Ways that marketing has been (mis)used to take advantage of ... vulnerable consumers are both multifarious and well known - not to mention deplorable', and it is similarly evident that, perceived as such, marketers are no longer in touch with the mood of the times. Despite this, there is evidence of a continued insistence on bucking the trend, of marketing against the tide. The 'blogosphere' for example is already replete with advice on 'recession marketing' how marketers/marketing can survive, succeed in, or exploit a downturn ('Recession responsible for marketing innovation!' - Ortiz, 2008). Much of this is stereotypically cynical - for example the CEO of the Association of National Advertisers says, in a series of advisory points to marketers: 
We're finally up to the last of the ten strategies on how to bounce back from tough times. My advice to you is to be socially responsible. Do the right thing. Your consumers will notice and reward you for giving back! (Liodice, 2009)

Other contributions, albeit focused on similar ends, are more thoughtful, and at least recognize the irony of the fix that marketers now find themselves in:

It seems that the viability of a campaign is no longer simply tied to potential sales results, but to its ethical implications and adherence to a set of vaguely austere criteria... The question that remains as yet unanswered is 'How do you effectively advertise products and services with the subtext that raging consumerism was a mistake?' (Sternberg, 2009)

We know though, instinctively, that our marketing managers will find a way ...

There is, though, according to Fromm (1949), an antidote to all this; for beyond the falsehoods and fabrications that characterize Fromm's marketing and exploitative characters, there lies another, more ethically assured, way forward. For this, the 'productive' character, or personality, must come to the fore:

In productive thinking the subject is not indifferent to his object but is affected by and concerned with it. The object is not experienced as something dead and divorced from oneself and one's life ... on the contrary, the subject is intensely interested in his object, and the more intimate this relation is, the more fruitful is his thinking. (Fromm, 1949: 103)

O'Malley et al. (2008) have declared the 'death' of the relationship metaphor, but the meaninglessness, or demise, of this device is only valid when seen in the context of marketing practice, rather than marketing theory. Fromm's ideas suggest that true customer-centricity is possible given the existence of truly customer-centric marketers.

Note also, that ' ... productive thinking is characterized by objectivity, by the respect the thinker has for his object, by his ability to see the object as it is, not as he wishes it to be' (Fromm, 1949: 104). And, in these circumstances, 'Objectivity does not mean detachment, it means respect; that is, the ability not to distort and falsify things, persons and oneself' (Fromm, 1949: 105). Schultz, II and Holbrook (2009) suggest that marketers and policymakers will only act in nondamaging ways if there are financial incentives to do so; but they also speculate on the possibility of marketers rising to the 'grand challenge' of reducing, rather than feeding off, consumer vulnerability. The task, clearly, is to cause organizations to see that fulfilling the long-term needs of society, and achieving the long-term viability of profitable customer/supplier relationships, are mutually supportive endeavours. But organizations, of course, are neither conscious, nor independently coordinated organisms. They are, perhaps too obviously, primarily collections of people, and only when people are 'productive', according to Fromm, can the tension between individual and collective (societal and organizational) needs be resolved (Elkind, 1981).

\section{The 'new' marketer/conclusion}

Surprisingly, given Fromm's early concerns with post-war consumerism and with 'homo consumens' (Fromm, 1966) - a term used to capture the essence of those in thrall to the market, and not dissimilar to Firat and Schultz, II's 1997 homo consumericus - there is little written about him in the marketing canon. Particular exceptions are articles by Cherrier and Murray (2007) and Shankar 
and Fitchett (2002), ${ }^{1}$ both of which focus on Fromm's dichotomous notion of 'having' (the self represented via consumption and ownership) and 'being' (identity established as a function of social/relational experience), an evolving theme ultimately formalized in Fromm (1979), but based upon earlier perspectives on the acquisitive nature of post-war society which he believed, presciently, would lead ultimately to 'economic catastrophe'. Shankar and Fitchett (2002) explore this device in the context of a revised form of marketing; a 'marketing of being', that promotes the benefits of social over material profit. They suggest that 'marketing activities must... be designed to facilitate being-ness rather than geared toward the short-term goal of satisfying the motivation and drive to have' (Shankar and Fitchett, 2002: 513). This requires that marketers face up to the possibility that the market is changing; to the likelihood that consumers are becoming tired of wanting and owning; and that service, experience and the need to be socially responsible are slowly edging out quantity and the continuous lust for more. There is a force field (Lewin, 1997; Thomas, 1985) at play (see Figure 1) and marketers are seemingly pushing against the tide.

But, of course, change will not emerge by accident; nor by the exhortations of a critical few. A 'marketing of being' will only materialize if marketers themselves believe in the relevance of such a singularity and if, psychologically, they are aligned to these same aspirations, or hold relevant job characteristic beliefs. Similarly, Schultz, II and Holbrook's (2009: 124) call for marketing to adopt 'efficacious practices for intervention' will only materialize if marketers are inclined to accede, and if their personality both allows and encourages this. Fromm identified that, of all his economically derived orientations, the productive personality is unique in its understanding of the 'being' mode (Boeree, 2006). To 'have' is to be divorced from responsibility and respect, and those who 'have' customers cannot possibly understand them. To 'have' is both to possess and to use; to collect, to categorize and exploit. Organizations will ultimately recognize that marketing has a social, as well as an organizational, role to play and that, ultimately, it will be in their best interests to seek out, and employ, the 'right' sort of employee. In 1987 Gummesson hailed the era of the 'new' marketing (Woodall, 2007); and now, perhaps, we are entering an era where 'productive' marketing - advanced, practised and promoted by the 'new' and productive marketer - might be the most appropriate way of proceeding.

Both in this paper, though, and in Woodall and Swailes (2009), it has been suggested that we know little about how marketing managers view their responsibilities to the customer; to society; to the long-run success of the wider economy; and to theoretically optimizing organizational strategies. We do, though, know much about the customer - how he/she is likely to think and act, and how personalities, proclivities and vulnerabilities might best be manipulated to the organization's advantage. We term this exploratory discipline 'consumer behaviour' (AMA, 2010), an established and comprehensively articulated conceptual domain widely represented through books, conference tracks and journals. What we require now, though, is an equally searching exploration of the marketer, so as to determine how he/she can be understood, educated, selected and trained to 'fit' the needs not just of business, but of society too; and how, also, marketer vulnerability - both moral and attitudinal - can be assessed, avoided and/or modified.

\section{An agenda for research}

We need, therefore, a means of helping assure that our marketers are psychologically and inherently - not just instrumentally and expediently - oriented toward the spirit of the marketing concept, with the robustness of will to resist the short-term, questionable and effortless solution. 


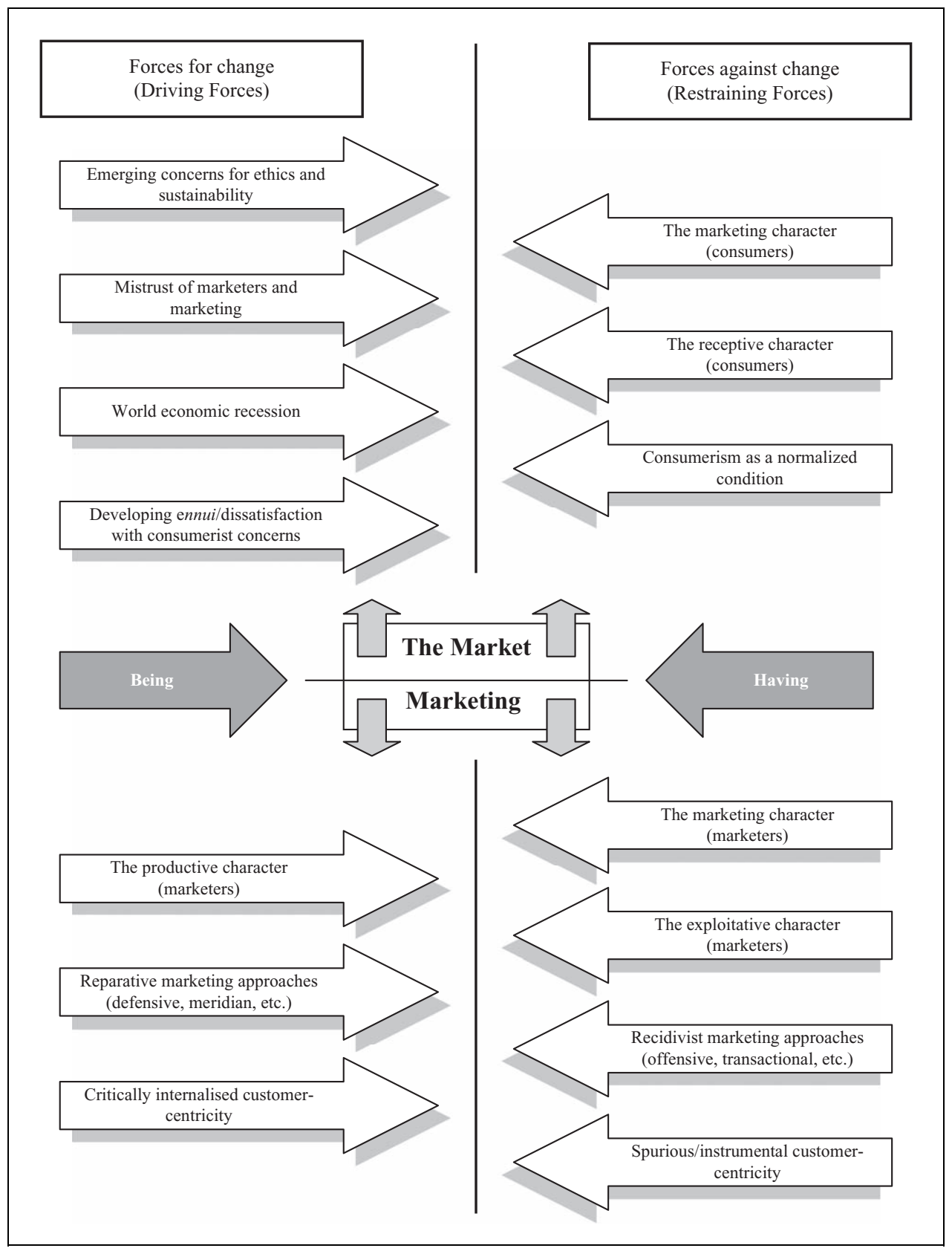

Figure I. Force Field Analysis - the Market and Marketing

And if we regard it necessary to break the cycle of interdependence between vulnerable marketer and vulnerable consumer, it would be naive to expect the latter to exercise restraint on our behalf. Figure 1, above, implies frailty on both sides of the line of equilibrium, but by focusing the bulk of 
our research activities on one side of the customer/marketing dyad only, we effectively ensure that the balance will always be in favour of those with the knowledge, the power and the inclination to exploit. The behaviour of marketing subjects (including marketing managers) should exercise the inquisitiveness of the marketing academy just as much as the behaviour of its objects; and if marketing is, indeed, to raise its standards and aspirations (Kelly and Smith, 2008; Schultz, II and Holbrook, 2009; Sheth and Sisodia, 2007) then we need, primarily, to identify the characteristics, and people, most likely to bring this to pass. There are, therefore, things we need to know:

1. How do aspirant marketers perceive the nature and notion of 'marketing' as (a) an organizational discipline, and (b) a career opportunity; and what is it that attracts individuals to the job of marketing manager?

2. Are particular 'types' of individual attracted to the job of marketing manager, and are the negative connotations often associated with marketing attractive to specific individuals?

3. To what extent do educational programmes themselves reinforce and/or modify preconceptions about marketing, and in which ways are the attitudes/objectives of aspirant marketing managers affected by the marketing programmes they study?

4. What proportion and/or type of individuals sustain an interest in marketing following the completion of their qualifications, and what discourages those who don't?

5. To what extent, and in which ways, does organizational and peer influence reinforce or modify post-education perceptions of how marketing management should be practised?

6. How do different stakeholders (society, organizations, marketers, the marketing academy) recognize 'success' in the context of marketing ...

7. ... and how do marketers react to, and/or prioritize, multiple stakeholder expectations?

8. What do marketers actually feel about consumers, and what do they understand by the notion of customer satisfaction and customer value?

9. How might we model and test the 'right' marketer (given that what is 'right' in one context may be inappropriate in another) and, ultimately, how can the productive marketer be identified and encouraged?

The study of consumer behaviour is both complex and continuously evolving, and subject to constant re-evaluation and refinement - not least as consumers, and the notion of consumption itself, inevitably change over time (Sassatelli, 2007). We are all constantly re-evaluating, (a) what it means to consume (Caruana, 2007), and (b) the role that consumption plays in our lives (Shankar et al., 2006). But what of the marketing manager; to what extent does he/she acknowledge and respond to these fundamental shifts in the public mood? And how do we, as academics, guide the process of change? Unless we understand, evaluate and adjust our perspectives on this key agent, then marketing will stagnate - not tactically nor stylistically; we know that marketing managers will continue to reinvent themselves and update superficially to accommodate the market rhetoric of the times - but philosophically, politically and, most importantly, socially. We should never assume that marketing can last forever, and there are many professions that society has left behind. To those who believe that society will adapt to them, rather than the reverse - beware; and remember the fate of the alchemist.

\section{Note}

1. See also Tadajewski (2010), published since going to press. 


\section{References}

Aaker, J.L. (1997) 'Dimensions of Brand Personality', Journal of Marketing Research 34(3): 347-56.

AMA (2010) 'American Marketing Association Resource Library, Dictionary', URL (consulted January 2010): http://www.marketingpower.com/_layouts/Dictionary.aspx?dLetter=C.

Ardley, B. (2005) 'Marketing Managers and Their World; Explorations in Strategic Planning Using the Phenomenological Interview', Marketing Review 5(2): 111-27.

Arnott, D.C. (2007) 'Trust - Current Thinking and Future Research', European Journal of Marketing 41(9/10): 981-7.

Arora, R. and Stoner, C. (2009) 'A Mixed Method Approach to Understanding Brand Personality', Journal of Product and Brand Management 18(4): 272-83.

Baker, S. and Holt, S. (2004) 'Making Marketers Accountable: A Failure of Marketing Education?', Marketing Intelligence \& Planning 22(5): 557-67.

Bardzil, P. and Slaski, M. (2003) 'Emotional Intelligence: Fundamental Competencies for Enhanced Service Provision', Managing Service Quality 13(2): 97-104.

Baudrillard, J. (1988) America. London: Verso.

Berry, L.L., Carbone, L.P. and Haeckel, S.H. (2002). 'Managing the Total Customer Experience', MIT Sloan Management Review 43(3): 85-9.

Black, J.A. (1984) 'The Path to “A Sane Society": A Note', American Economist 28(2): 76-80.

Boeree, C.G. (2006) 'Personality Theories: Erich Fromm, 1900-1980', URL (consulted May 2006):http:// www.ship.edu/ cgboeree/fromm.html.

Borgerson, J.L. and Schroeder, J.E. (2002) 'Ethical Issues of Global Marketing: Avoiding Bad Faith in Visual Representation', European Journal of Marketing 36: 570-94.

Brady, M. and Palmer, R. (2004) 'What Are They Doing? A Study of Contemporary Marketing Practice in Ireland', Irish Journal of Management 25(1): 125-36.

Brill, J. (1994) 'Beyond Managerial Opportunism: Supplier Power and Managerial Compliance in a Franchised Marketing Channel', Journal of Business Research 30(3): 221-3.

Brinkmann, J. (2002) 'Business and Marketing Ethics as Professional Ethics: Concepts, Approaches and Typologies', Journal of Business Ethics 41(1/2): 159-77.

Brown, M.T., White, M.J. and Gerstein, L.H. (1989) 'Self-monitoring Processes and Holland Vocational Preferences among College Students', Journal of Counseling Psychology 36(2): 183-8.

Brown, S. (2000) 'Going Bananas in Paradise: From McDonaldisation to Ffyfification', Marketing Intelligence and Planning 18(6/7): 356-67.

Brown, S. (2001) Marketing - The Retro Revolution. London: Sage.

Brown, S. (2006) The Marketing Code. London/Singapore: Cyan Communications/Marshall Cavendish Business.

Brown, S. (2007a) 'The Failgood Factor: Playing Hopscotch in the Marketing Minefield', Marketing Review 7(2): $125-38$

Brown, S. (2007b) 'Rosmerta Marketing: Introduction to the Second Celtic Special Issue', Journal of Strategic Marketing 15(1): 1-6.

Brown, S. and Patterson, A. (2000). 'Trade Softly because You Trade on My Dreams: A Paradisal Prolegomenon'. Marketing Intelligence and Planning 18(6/7): 316-20.

Carless, S.A. (2005) 'Person-job Fit versus Organisation-job Fit as Predictors of Organisational Attraction and Job Acceptance Intention: A Longitudinal Study', Journal of Occupational and Organisational Psychology 78: 411-29.

Carroll, A.B. (1999) 'Corporate Social Responsibility: Evolution of a Definitional Construct', Business and Society 38(3): 268-95.

Carter, S. (1985) 'Is This the Stuff that Marketers are Made of?', European Journal of Marketing 19(6): 53-64.

Caruana, R. (2007) 'A Sociological Perspective on Consumption Morality', Journal of Consumer Behaviour 6(5): 287-304. 
Celmer, V. and Winer, J.L. (1990) 'Female Aspirants to the Roman Catholic Priesthood', Journal of Counseling and Development 69(November/December): 178-83.

Chang, C-C. (2006) 'When Service Fails: The Role of the Salesperson and the Customer', Psychology and Marketing 23(3): 203-24.

Chang, L. and Arkin, R.M. (2002) 'Materialism as an Attempt to Cope with Uncertainty', Psychology and Marketing 19(5): 37-44.

Cherrier, H. and Murray, J.B. (2007) 'Reflexive Dispossession and the Self: Constructing a Processual Theory of Identity', Consumption, Markets and Culture 10(1): 1-29.

Clark, B.H. (2000) 'Managerial Perceptions of Marketing Performance: Efficiency, Adaptability, Effectiveness and Satisfaction', Journal of Strategic Marketing 8(1): 3-25.

Converse, P.D., Oswald, F.L., Gillespie, M.A., Field, K.A. and Bizot, E.B. (2004) 'Matching Individuals to Occupations Using Abilities and the O*NET: Issues and an Application in Career Guidance', Personnel Psychology 57: 451-87.

Cova, B. (2005) 'Thinking of Marketing in Meridian Terms', Marketing Theory 5(2): 205-14.

Coviello, N.E., Brodie, R., Danaher, P.J. and Johnston, W.J. (2002) 'How Firms Relate to their Markets: An Empirical Examination of Contemporary Marketing Practices', Journal of Marketing 66(3): 33-46.

Daulatram, L. (2008) 'Gender Differences in Ethics Judgement of Marketing Professionals in the United States', Journal of Business Ethics 77(4): 501-15.

Davis, H.B. (2003) 'Erich Fromm and Postmodernism', Psychoanalytic Review 6: 839-53.

Day, G.E. (1994) 'The Capabilities of Market-driven Organisations', Journal of Marketing 58: 37-52.

de Graaf, J., Wann, T. and Naylor, T. (2001) Affluenza: The All-consuming Epidemic. San Francisco, CA: Berrett-Koehler.

Deconinck, J. (2004) 'The Effect of Ethical Climate and Moral Intensity on Marketing Managers' Ethical Perceptions and Behavioural Intentions', Marketing Management Journal 14(1): 129-37.

Ehrhart, K. (2006) 'Job Characteristic Beliefs and Personality as Antecedents of Subjective Person-job Fit', Journal of Business and Psychology 21(2): 193-226.

Elkind, D. (1981) 'Obituary: Erich Fromm (1900-1980)', American Psychologist 36(5): 521-2.

Elliot, K. and Margerison, C. (1977) ‘The Marketing Man's Image of Himself and His Work Relationships', European Journal of Marketing 11(1): 42-50.

Farmer, R.N. (1967) 'Would You Want Your Daughter to Marry a Marketing Man?', Journal of Marketing 33(1): 1-3.

Farmer, R.N. (1977) 'Would You Want Your Son to Marry a Marketing Lady?', Journal of Marketing 41(1): $15-18$.

Farrell, M.A. and Oczkowski, E. (2009) 'Service Worker Customer Orientation, Organisation/Job Fit and Perceived Organisational Support', Journal of Strategic Marketing 17(2): 149-67.

Ferrell, O.C. and Weaver, K.M. (1978) 'Ethical Beliefs of Marketing Managers', Journal of Marketing 42(3): 69-72.

Firat, A.F. and Schultz, C.J., II (1997) 'From Segmentation to Fragmentation', European Journal of Marketing 31(3/4): 183-207.

Firat, A.F. and Venkatesh, A. (1995) 'Liberatory Postmodernism and the Re-enchantment of Consumption', Journal of Consumer Research 22(3): 239-67.

Forlani, D., Mullins, J.W., and Walker, O.C., Jr (2002) 'New Product Decision Making: How Chance and Size of Loss Influence What Marketing Managers See and Do', Psychology and Marketing 19(11): 957-81.

Franke, G.R. and Park, J-E. (2005) 'Salesperson Adaptive Selling Behaviour and Customer Orientation: A Meta-analysis', Journal of Marketing Research 43(4): 693-702.

Fritzsche, D.J. and Becker, H. (1983) 'Ethical Behaviour of Marketing Managers' Journal of Business Ethics 2(4): 291-9.

Fromm, E. (1941) Escape from Freedom. New York: Holt, Rinehart and Winston.

Fromm, E. (1949) Man for Himself. London: Routledge and Keegan Paul. 
Fromm, E. (1955 [1991]) The Sane Society (2nd enlarged ed.). London: Routledge.

Fromm, E. (1956) The Art of Loving. New York: Bantam Books.

Fromm, E. (1966) 'The Psychological Aspects of the Guaranteed Income', URL (consulted May 2009): http:// www.erich-fromm.de/data/pdf/1966c-e.pdf.

Fromm, E. (1979) To Have or To Be? London: Abacus.

Fromm, E. and Maccoby, M. (1970) Social Character in a Mexican Village. New Brunswick, NJ: Transaction Publishers.

Furnham, A. (2001) 'Personality and Individual Differences', in B. W. Roberts and R. Hogan (eds) Personality Psychology in the Workplace, pp. 223-51. Washington, DC: American Psychological Association.

Gaski, J.F. (1999) 'Does Marketing Ethics Really Have Anything to Say? A Critical Inventory of the Literature', Journal of Business Ethics 18(3): 315-34.

Geuens, M. (2009) 'A New Measure of Brand Personality', International Journal of Research in Marketing 26(2): 97-107.

Gibbs, P. and Ilkan, M. (2008) 'The Ethics of Marketing in Islamic and Christian Communities', Cross Cultural Management 15(2): 162-75.

Green, A.W. (1946) 'Sociological Analysis of Horney and Fromm', American Journal of Sociology 51(6): 533-40.

Grönroos, C. (2006) 'On Defining Marketing: Finding a New Roadmap for Marketing', Marketing Theory 6(4): 395-417.

Gruba-McCallister, F. (2007) 'Narcissism and the Empty Self: To Have or To Be', Journal of Individual Psychology 63(2): 182-92.

Gummesson, E. (1987) 'The New Marketing - Developing Long Term Interactive Relationships', Long Range Planning 20(4): 10-20.

Gummesson, E. (1991) 'Marketing-orientation Revisited: The Crucial Role of the Part-time Marketer', European Journal of Marketing 25(2): 60-75.

Harris, E.G. and Fleming, D.E. (2005) 'Assessing the Human Element in Service Personality Formation: Personality Congruence and the Five Factor Model', Journal of Services Marketing 19(4): 187-98.

Hayes, B., Alford, B.L., Silver, L. and York, R.P. (2006) 'Looks Matter in Developing Consumer-brand Relationships', Journal of Product \& Brand Management 15(5): 306-15.

Heath, M.T.P. and Heath, M. (2008) '(Mis)trust in Marketing: A Reflection on Consumers' Attitudes and Perceptions', Journal of Marketing Management 24(9/10): 1025-39.

Hunt, S.D. and Chonko, L.B. (1984) 'Marketing and Machiavellianism', Journal of Marketing 48(summer): $30-42$.

i-level (2009) 'Responsibility for the Recession', URL (consulted June 2009): http://www.ilevel.ie/2009/04/ responsibility-for-the-recession/ilevel(2009).

Järlström, M. (2000) 'Personality Preferences and Career Expectations of Finnish Business Students', Career Development International 5(3): 144-54.

Jobber, D. (2010) Principles and Practices of Marketing (6th ed.). Maidenhead: McGraw-Hill Education.

Johnson, A., Winter, P.A., Reio, T.G., Jr, Thompson, H.L. and Petrosko, J.M. (2008) 'Managerial Recruitment: The Influence of Personality and Ideal Candidate Characteristics', Journal of Managerial Recruitment 27(6): 631-48.

Karande, K., Rao, C.P. and Singhapakdi, A. (2002) 'Moral Philosophies of Marketing Managers: A Comparison of American, Australian and Malaysian Cultures', European Journal of Marketing 36(7/8): 768-91.

Kelly, D.M. and Smith, N.C. (2008) 'Commercialising Social Interaction: The Ethics of Stealth Marketing', Journal of Public Policy and Marketing 27(1): 46-56.

Kohli, A.K. and Jaworski, B.J. (1990) 'Market Orientation: The Construct, Research Propositions, and Managerial Implications', Journal of Marketing 54(2): 1-18.

Kotler, P. (1972) ‘A Generic Concept of Marketing', Journal of Marketing 36(2): 46-54. 
Kucharsky, D. (2002) 'Jaques Nantel's Got Personality', Marketing Magazine 107(21), abstract, Business Source Premier, URL (consulted April 2006): http://search.epnet.com.

Kumar, V. (2008) 'Cross-buying in Retailing: Drivers and Consequences', Journal of Retailing 84(1): 15-27. Kumar, V., Peterson, J.A. and Leone, R.P. (2007) 'How Valuable is Word of Mouth?', Harvard Business Review 85(10): 139-46.

Lawer, C. and Knox, C. (2006) 'Customer Advocacy and Brand Development', Journal of Product and Brand Management 15(2): 121-9.

Lewin, K. (1997) Resolving Social Conflicts and Field Theory in Social Science. Washington, DC: American Psychological Association.

Liodice, R. (2009) 'ANA Marketing Musings', URL (consulted June 2009): http://ana.blogs.com/liodice/ 2009/04/recession-marketing-vglobe-socially-responsible.html.

Lysonski, S., Durvasula, S. and Watson, J. (2003) 'Should Marketing Managers Be Concerned about Attitudes towards Marketing and Consumerism in New Zealand? A Longitudinal View', European Journal of Marketing 37(3/4): 385-406.

Maccoby, M. (2004) 'Narcissistic Leaders: The Incredible Pros, the Inevitable Cons', Harvard Business Review 82(1): 92-101.

McDaniel, S.W. and Rylander, D.H. (1993) 'Strategic Green Marketing', Journal of Consumer Marketing 10(3): 4-10.

Mackrill, R. (2007) 'UK Consumer Debt More than GDP', Daily Reckoning (UK ed.), URL (consulted June 2009): http://www.dailyreckoning.co.uk/economic-forecasts/uk-consumer-debt-more-than-gdp.html.

McLaughlin, N. (1998) 'How to become a Forgotten Intellectual: Intellectual Movements and the Rise and Fall of Erich Fromm', Sociological Forum 13(2): 215-46.

McPherson, W. (1996) 'Makin' Your Marketing Personality Work for You', Educational Resources Information Center, abstract, Business Source Premier, URL (consulted April 2006): http://search.epnet.com.

Marta, J., Heiss, C. and Lurgio, S. (2008) 'An Exploratory Comparison of Ethical Perceptions of Mexican and US Marketers', Journal of Business Ethics 82(3): 539-55.

Marta, J., Singhapakdi, A. and Kraft, K. (2008) 'Personal Characteristics Underlying Ethical Decisions in Marketing Situations: A Survey of Small Business Managers', Journal of Small Business Management 46(4): 589-606.

Martin, K. and Johnson, J.L. (2008) ‘A Framework for Ethical Conformity in Marketing', Journal of Business Ethics 80(1): 103-9.

Master, M. (2003) 'Michael Maccoby Wants to Know Your Type', Across the Board, May/June, pp. 13-14.

Mattsson, J., Ramaseshan, R. and Carson, D. (2006) 'Let Marketers Reclaim Corporate Strategy', Journal of Strategic Marketing 14(2): 61-77.

Maycroft, N. (2004) 'Cultural Consumption and the Myth of Life-style', Capital and Class 84: 61-75.

Mayo, M.A. and Marks, L.J. (1990) 'An Empirical Investigation of a General Theory of Marketing Ethics', Journal of the Academy of Marketing Science 18(2): 163-71.

Meisenhelder, T. (2006) 'From Character to Habitus in Sociology', Social Science Journal 43(1): 55-66.

Monster (2009) 'Vacancies', URL (consulted October 2009): http://jobsearch.sales.monster.co.uk.

Morgan, R., McDonagh, P. and Ryan-Morgan, T. (1995) 'Employee Job Satisfaction: An Empirical Assessment of Marketing Managers as an Occupationally Homogeneous Group', Journal of Managerial Psychology 10(2): 10-17.

Murphy, P.E., Laczniak, G.R. and Wood, G. (2007) 'An Ethical Basis for Relationship Marketing: A Virtue Ethics Perspective', European Journal of Marketing 41(1/2): 33-57.

Narver, J.C. and Slater, S.F. (1990) 'The Effect of a Market Orientation on Business Profitability', Journal of Marketing 54(4): 20-35.

Newlin, L. (2002) 'Marketing with Personality', American Nurseryman February: 28-30.

Nördvik, H. (1996) 'Relationships between Holland's Vocational Typology, Schein's Career Anchors and Myers-Briggs' Types', Journal of Occupational and Organisational Psychology 69(3): 263-75.

Olsen, M.E. (1965) ‘Durkheim's Two Concepts of Anomie', Sociological Quarterly 6(1): 37-44. 
O’Malley, L. and Prothero, A. (2004) 'Beyond the Frills of Relationship Marketing', Journal of Business Research 57(11): 1286-94.

O'Malley, L., Patterson, M. and Holmes, H. (2008) 'Death of a Metaphor: Reviewing the "Marketing as Relationships" Frame', Marketing Theory 8(2): 167-87.

Ortiz, S. (2008) 'Recession Responsible for Marketing Innovation', URL (consulted June 2009): http:// rrwdatabasemarketing.blogspot.com/2008/03/recession-responsible-for-marketing.html.

Packard, V. (1957) The Hidden Persuaders. New York: McKay.

Pearlstein, S. (2007) “"No Money Down” Falls Flat', Washington Post (online), URL (consulted June 2009): http://www.washingtonpost.com/wp-dyn/content/article/2007/03/13/AR2007031301733_ pf.html.

Pendse, S.G. (1978) ‘An Empirical Validity Test of Fromm's Personality Orientations Theory', Journal of General Psychology 99(1): 133-9.

Peters, L., Gassenheimer, J.B. and Johnston, W.J. (2009) 'Marketing and the Structuration of Organisational Learning', Marketing Theory 9(3): 341-68.

Promagazine (2003) 'Brand Names', Promagazine 16(2): 28-36.

Rallapalli, K.C., Vitell, S.J., Jr and Szeinbach, S. (2000) 'Marketers' Norms and Personal Values: An Empirical Study of Marketing Professionals', Journal of Business Ethics 24(1): 65-75.

Rasmussen, B. and Sulhani, D (2008). 'Resurrecting Erich Fromm', Smith College Studies in Social Work 78(2): 201-25.

Reichheld, F.F. (1996) The Loyalty Effect. Boston, MA: Harvard Business Press.

Rickert, J. (1986) 'The Fromm-Marcuse Debate Revisited', Theory and Society 15(3): 351-400.

Roberts, B.W. and Hogan, R. (2001) Personality Psychology in the Workplace. Washington, DC: American Psychological Association.

Rust, R.T., Lemon, K.N. and Zeithaml, V.A. (2004) 'Return on Marketing: Using Customer Equity to Focus Marketing Strategy’, Journal of Marketing 68(10): 109-27.

Saarksjarvi, M., Hellen, K., Gummerus, J. and Grönroos, C. (2007) 'Love at First Sight or a Long-term Affair? Different Relationship Levels as Predictors of Customer Commitment', Journal of Relationship Marketing 6(1): 45-61.

Samuelson, R.J. (2007) 'Beyond the Sub-prime Debacle', Washington Post (online), URL (consulted June 2009): http://www.washingtonpost.com/wp-dyn/content/article/2007/03/27/AR2007032701721. html.

Sassatelli, R. (2007) Consumer Culture: History, Theory and Politics. London: Sage.

Saunders, S. and Munro, D. (2000) 'The Construction and Validation of a Consumer Orientation Questionnaire (SCOI) Designed to Measure Fromm's (1955) "Marketing Character" in Australia', Social Behaviour and Personality 28(3): 219-40.

Sawyerr, O., Srinvas, S. and Wang, S. (2009) 'Call Centre Employee Personality Factors and Service Performance', Journal of Services Marketing 23(5): 301-17.

Schein, E. (1996) Career Anchors (Discovering Your Real Values). San Francisco, CA: Jossey-Bass Pfeiffer.

Schlegelmilch, B.B. and Öberseder, M. (2010) 'Half a Century of Marketing Ethics: Shifting Perspectives and Emerging Trends', Journal of Business Ethics 93(1): 1-19.

Schultz, C.J., II and Holbrook, M. (2009) 'The Paradoxical Relationships between Marketing and Vulnerability', Journal of Public Policy and Marketing 28(1): 124-7.

Scott, L.M. and Peñaloza, L.O. (2006) 'Matriarchal Marketing: A Manifesto', Journal of Strategic Marketing 14(1): 56-67.

Search Engine College (2009) 'Search Engine Marketing Personalities Category', URL (consulted October 2009): http://www.searchenginewiki.com/CategoryPersonalities.

Shankar, A. and Fitchett, J.A. (2002) 'Having, Being and Consumption', Journal of Marketing Management 18(5/6): 501-16.

Shankar, A., Whittaker, J. and Fitchett, J.A. (2006) 'Heaven Knows I'm Miserable Now', Marketing Theory 6(4): 485-505. 
Sheth, J.N and Sisodia, R.S. (2005) “"Does Marketing Need Reform?", in Marketing Renaissance: Opportunities and Imperatives for Improving Marketing Thought, Practice, and Infrastructure, edited by R. Bolton', Journal of Marketing 69(4): 10-12.

Sheth, J.N. and Sisodia, R.S. (2007) 'Raising Marketing Aspirations', Journal of Public Policy and Marketing 26(1): 141-3.

Simply Marketing Jobs (2009) 'Vacancies', URL (consulted October 2009): http://www.simplymarketingjobs. co.uk.

Singhapakdi, A. and Vitell, S.J. (2007) 'Institutionalisation of Ethics and its Consequences: A Survey of Marketing Professionals', Journal of the Academy of Marketing Science 35(2): 284-94.

Singhapakdi, A., Rao, C.P. and Vitell, S.J. (1996) 'Ethical Decision Making: An Investigation of Services Marketing Professionals', Journal of Business Ethics 15(6): 635-44.

Singhapakdi, A., Gopinath, M., Marta, J. and Carter, L. (2008) 'Antecedents and Consequences of Perceived Importance of Ethics in Marketing Situations: A Study of Thai Businesspeople', Journal of Business Ethics 81(4): 887-904.

Singhapakdi, A., Sirgy, M.J., Lee, D-J., and Vitell, S.J. (2010) 'The Effects of Ethics Institutionalisation on Marketing Managers: The Mediating Role of Implicit Institutionalisation and the Moderating Role of Socialisation', Journal of Macromarketing 30(1): 77-92.

Sternberg, N. (2009) 'Hard Times, Good Intentions: Moral Marketing in a Recession', URL (consulted August 2009): http://threeminds.organic.com/2009/02/moral_marketing_in_a_recession.html.

Stock, M.S. and Hoyer, W.D. (2005) 'An Attitude-Behaviour Model of Salespeople's Customer Orientation', Journal of the Academy of Marketing Science 33(4): 536-52.

Tadajewski, M. (2010) 'Towards a History of Critical Marketing Studies', Journal of Marketing Management 26(9/10): 773-824.

Tett, R.P. and Burnett, D.D. (2003) 'A Personality Trait-based Interactionist Model of Job Performance', Journal of Applied Psychology 88(3): 500-17.

Thomas, A., Buboltz, W.C. and Winkelspecht, C.S. (2004) 'Job Characteristics and Personality as Predictors of Job Satisfaction', Organisational Analysis 12(2): 205-19.

Thomas, J. (1985). 'Force Field Analysis: A New Way to Evaluate Your Strategy', Long Range Planning 18(6): 54-9.

Urban, G.L. (2005) 'Customer Advocacy: A New Era In Marketing?', Journal of Public Policy and Marketing 24(1): 155-9.

Vargo, S.L. and Lusch, R.F. (2008) 'Service-dominant Logic: Continuing the Evolution', Journal of the Academy of Marketing Science 36(1): 1-10.

Verbeke, W. and Bagozzi, R.P. (2002) 'A Situational Analysis on How Salespeople Experience and Cope with Shame and Embarrassment', Psychology and Marketing 19(9): 713-41.

Vikas, R.M. and Varman, R. (2007) 'Erasing Futures: Ethics of Marketing an Intoxicant to Homeless Children', Consumption, Markets and Culture 10(2): 189-202.

Vitell, S.J. and Hunt, S.D. (1990) 'The General Theory of Marketing Ethics: A Partial Test of the Model', Research in Marketing 10: 237-55.

Walsh-Bowers, R. (1993) 'Review of the Legacy of Erich Fromm', Canadian Psychology 2: 217-19.

Weber, J.A. (2001) 'Illusions of Marketing Planners', Psychology and Marketing 18(6): 527-63.

Wilk, S.L., Desmarais, L.B. and Sackett, P.R. (1995) 'Gravitation to Jobs Commensurate with Ability: Longitudinal and Cross-sectional Tests', Journal of Applied Psychology 80(1): 79-85.

Woodall, T. (2001) 'The Epistobabble Kid Rides again: A Stephen Brown (Selective) Retrospective', Marketing Review 2(2): 147-67.

Woodall, T. (2004) 'Why Marketers Don't Market: Rethinking Offensive and Defensive Archetypes', Journal of Marketing Management 20(5-6): 559-76.

Woodall, T. (2007) 'New Marketing; Improved Marketing; Apocryphal Marketing: Is One Marketing Concept enough?' European Journal of Marketing 41(11/12): 1284-96. 
Woodall, T. and Swailes, S. (2009) 'Conceptualising and Measuring Defensive Marketing Orientation (DMO): Some Inaugural Thoughts on Marketing's Place in "Society's Doghouse", Journal of Strategic Marketing 17(5): 345-64.

Young, L. (2004) 'For and by Brand Builders', Marketing Magazine, 109(5), Business Source Premier, URL (consulted April 2006): http://search.epnet.com.

Tony Woodall is a Principal Lecturer at Nottingham Business School, Nottingham Trent University, and lectures primarily in services marketing and in critical marketing. Research interests are consumer value and marketer behaviour; associated papers have appeared in the Journal of Marketing Management, the European Journal of Marketing, the Journal of Marketing Strategy and the Academy of Marketing Science Review. Address: Division of Marketing, Retail and Operations, Nottingham Business School, Nottingham Trent University, Burton Street, Nottingham NG16 2TG. [email: tony.woodall@ntu.ac.uk] 